\title{
Analysis and Exploration of Critical Success Factors of ERP Implementation: A Brief Review
}

\author{
Mohammed A. T. AISudairi, PhD. \\ Department of Management Information Systems \\ College of Business Administration \\ King Saud University
}

\begin{abstract}
Recent changes in business environment as a result of deregulation, privatization, globalization and consequently by the increased competition, organizations are struggling to survive and getting successfully run their organization towards sustainability. The rising intensity of competition and the pressures for operational excellence, customer intimacy, and innovation are motivating firms to restructure their business processes and information flows. A new breed of information systems, termed as enterprise systems, is being implemented to reengineer outdated business processes and integrate information flows across the enterprise. The ERP system is one of the salient solutions being used to accomplish the organizational need for integration and business processes solutions. Although ERP implementation is a risky task and expensive proposition, it can provide a variety of benefits to the organization, especially in engaging white-business initiatives. Therefore, the successful implementation of ERP projects is an important priority. There are several challenges to the successful implementation of an ERP. This paper will integrate existing ideas about the critical successful factors for guiding an ERP implementation. The resulting framework should provide direction for future research and practice..
\end{abstract}

\section{Keywords}

Benefits of ERP, Challenges in ERP, Critical Success Factors of ERP, ERP Critical Success Factors, Successful ERP Implementation.

\section{INTRODUCTION}

Globalization is characterized by increasing interconnectivity, increase in diversity, rapid but discontinuous change and greater managerial complexity [32]. For example, the globalization trend has caused businesses to compete and distribute their products and services in different countries [35]. The irregular nature of change in the environment is causing the economic crisis [32]. Economic weak spots are integrated into the global economy. Firms around the world often must manage and survive at this economic crisis. As global integration between firms and countries continues to march forward, managers and strategy analysts will have to find new ways to deal with globalization. Many of the founding assumptions of multinational corporation strategy have undergone radical change [29]. With this kind of impending move toward globalization and liberalization of markets, organizations have to be prepared to cope up with the rapid changes in business by responding appropriately to the varying demands and changes in the environment [33]. The contemporary globalization that is experiencing today is driven by a confluence of forces such as economic shifts, technology shifts, political shifts and economic shifts. One of the better management techniques to this kind of economic crisis is the adoption of resource-based perspective to identify organizational capabilities that would help firms manage their way out of an economic crisis. Two such capabilities are: (i) market orientation and (ii) strategic flexibility [34]. The concept of think globally and act locally has become the business phrase of the twentieth century. The economic world has shifted from being a cluster of national economies to a global and more interdependent marketplace. Crossing borders both physically and electronically is becoming increasingly vital for even smallest businesses remain competitive. [31]. The move away from nationally focused business units to a global market focus requires an effective international co-ordination of firm's activities [2]. It means extensive use of organizational resources that embody stocks of knowledge, physical assets, human capabilities and other tangible and intangible factors that a business owns and controls; which enable a firm to become effective and efficient; creating and adding value to the organization with market orientation and strategic flexibility [34, 25]. The adoption of the flexible specialization strategy implied action for extensive organizational reform [30]. As organizations and markets become more international, individual firms must respond to appropriate market and IT strategies [41]. ICT innovation has a crucial role to play in going beyond the technical/rational actions of its professional activities towards addressing such inter-networked organizational reforms taken place recently in order to lead to desirable effects of economic performance and social change in order to facilitate the exploitation of technological potential in relation to socioorganizational processes of change within which innovation is embedded [30]. One of the models of addressing above mentioned situation is to look for a better strategic driving model for electronic enterprises and enterprise level ebusiness solutions [50]. More specifically, the strategic view of the global market taken by an organization will affect the underlying IT infrastructure [2]. An awareness of increased environmental turbulence and attention to organizational reforms is identified as a core organizational capability by corporate Top management and started thinking about successful Change Management techniques in order to survive and succeed in the present highly competitive and continuously evolving business environment [38].

Business Process Reengineering (BPR) is one of such methodologies, because it is the fundamental rethinking and radical redesign of the business processes to achieve dramatic improvements in critical contemporary measures of performance such as cost quality, service and speed [40]. Some scholars argue that BPR is a derivative of scientific management and further enhanced by value chain concept [51] and hence the non value adding process should be obliterated rather than improving or automating them [39]. [42]'s research studied the evolution of reengineering and its evolution toward the broader notion of process change 
management. According to the study, BPR implementation promotes process change management. BPR focuses on sound principles such as: organizational outcomes, organizational processes and their priorities, integrated information processing; providing objective approach to geographical dispersions from centralization; achieving integration thorough workflow, building process controls, data collection at the source [37, 43]. There are five aspects of process management that lead to effective organizational change management with BPR methodology viz. (i) change management - focuses on communication of change, rewarding employees, encouraging involvement and creativity; (ii) project management - focuses on project management tools, organizing the project teams, monitoring progress, costs etc., (iii) continuous process management focuses on ongoing evaluation and monitoring of the processes (iv) strategic planning - focuses on setting goals for the organization regarding change, planning for change, setting strategic direction from the top; and (v) technology management - selecting technologies, developing information architectures, obtaining expertise. The Project Management aspect has a strong relationship towards leading to success as it contains broader organizational involvement. In addition, project management involving team-based approaches has a strong relationship in succeeding towards improving employee morale. The Change Management aspect has a strong relationship towards leading to success as it has a potential to deal with problems related to organization politics, resistance to change and communication management [42]. The ERP implementation had been adopted as one of the important techniques of BPR methodology as it has a capability of use of IT to create radically different working methods in order to achieve organizational improvement [44].

The key underlying benefit of ERP implementation is the capability to plan and integrate enterprise-wide resources at the level of applications, systems of a business. It provides an understanding on the way business processes and enterprise policies are structured. Though it is expressed by some authors $[45,46,52]$ that a better fit of ERP with the company's processes can be found as a benefit, however the efforts are required in terms of either modifying the software to achieve the fit (i) easy (only $29 \%$ of the survey respondents expressed) or (ii) business process re-engineering is required.

Table 1: The list of benefits against each of these key success factors has been tabulated as given below [47, 48, 53 ].

\begin{tabular}{|c|c|c|c|c|}
\hline $\begin{array}{l}\text { S. } \\
\text { No. }\end{array}$ & $\begin{array}{l}\text { Key } \text { Successful } \\
\text { Factor }\end{array}$ & Benefits & Type of Benefit & $\begin{array}{l}\text { Potential Grouping } \\
\text { Aspect }\end{array}$ \\
\hline 1. & IT Infrastructure & $\begin{array}{l}\text { Increased Business Flexibility, IT cost reduction, Increased } \\
\text { functional capability }\end{array}$ & $\begin{array}{l}\text { Infrastructural } \\
\text { Benefits }\end{array}$ & Technology \\
\hline 2. & $\begin{array}{l}\text { Top Management } \\
\text { Support }\end{array}$ & $\begin{array}{l}\text { Support for Business Growth Plan, Support for Alliances, } \\
\text { Support for Business innovation, Support for cost } \\
\text { leadership, support for product differentiation, global } \\
\text { expansion, conduct of e-business }\end{array}$ & $\begin{array}{l}\text { Strategic } \\
\text { Benefits }\end{array}$ & People \\
\hline 3. & $\begin{array}{l}\text { Change } \\
\text { Management }\end{array}$ & $\begin{array}{l}\text { Support for business organizational change, changed } \\
\text { culture with common vision, changed employee culture } \\
\text { with a sifted focus, better employee morale and satisfaction, }\end{array}$ & $\begin{array}{l}\text { Organizational } \\
\text { Benefits }\end{array}$ & Process \\
\hline 4. & $\begin{array}{l}\text { Business Process } \\
\text { Re-Engineering }\end{array}$ & $\begin{array}{l}\text { Cost Reduction, Cycle time reduction, productivity } \\
\text { improvement, data quality improvement, customer service } \\
\text { improvement }\end{array}$ & $\begin{array}{l}\text { Operational } \\
\text { Benefits }\end{array}$ & Process \\
\hline 5. & $\begin{array}{l}\text { Project } \\
\text { Management }\end{array}$ & $\begin{array}{l}\text { Better resource management, better performance control, } \\
\text { better decision making }\end{array}$ & $\begin{array}{l}\text { Managerial } \\
\text { Benefits }\end{array}$ & $\begin{array}{l}\text { A hybrid aspect of } \\
\text { technology, people } \\
\text { and process }\end{array}$ \\
\hline 6. & Communication & $\begin{array}{l}\text { Increased internal communication, improved co-ordination } \\
\text { between departments }\end{array}$ & $\begin{array}{l}\text { Managerial } \\
\text { Benefits }\end{array}$ & Process \\
\hline 7. & User Training & Facilitate employee learning and skills empowerment, & $\begin{array}{l}\text { Organizational } \\
\text { benefit }\end{array}$ & People \\
\hline
\end{tabular}

\section{Why do firms need ERP?.}

While there are unparalleled performance benefits in integrating enterprise systems, achieving effective integration remains very problematic due to numerous technological and organizational challenges [46]. There are situations where organizations were not successful in reaping the potential benefits that motivated them to make large investments in ERP implementation [45, 46] and faced several of these challenges such as:., (i) the technology is complex, (ii) the implementation requires changes to the existing processes and structures which are harder and take time, (iii) there is a potential for behavioral resistance to change. People do not understand the necessity for the change. They fail to buy-in to the need for the change and feel anxious and threatened about the demands.. ERP system project is a challenging task and high budget proposition because it has incredible demands on organization time and resources $[1,6]$. Therefore ERP system can harvest massive benefits for organizations to have successful implementation otherwise can lead to precarious consequences if not considered carefully [2]. ERP systems are integrated software packages which are developed by vendors to adapt the specific needs of each customer [4]. ERP is not only a process of computerization of business processes in organization, but this is a vision of automation to reengineer the business process of an organization to get benefits for long term success [11]. ERP systems are capable to reach beyond the organizations wall and connect the business concern people with organizations in e-business [6]. ERP systems are wide-ranging and integrated software packages which provide automated support for the standard business processes in the entire organization [7]. In other words ERP systems are the standard modules implementation for business processes that is combined with modified customization for competitive business differentiation [13]. 
Therefore, the successful management of ERP projects requires attention on many fronts. Analysis and exploration of critical success factors are tremendously a challenging process for many organizations worldwide in implementing ERP systems [5]. Critical success factors specifically useful for practitioners because they provide clear guidance to focus on resources and planning on the ERP implementation projects [7]. The literature shows that many efforts conducted in last few years to identify the success and failure factors of ERP implementation[12, 16] and critical success factors are therefore defined as the "few key area where the things must go right for the successful implementation" [1]. Critical Success factor approach is not only limited to researchers but it is extended to managers because it facilitates the identification and prioritization of factors that affect the implementation success $[16,17]$.

In spite of the fact that ERP systems have potential to reshape the business structures and business processes of the business organization. They promise the challenges posed by portfolios of supposedly disconnected and uncoordinated business applications [46].

\section{METHODOLOGY}

To analyze and explore the Critical Success Factors of Implementing Systems of ERP applications, a thorough literature has been reviewed for this paper to investigate the importance of these factors in ERP system implementation. There was no special tool used to extract the Critical Success Factors but the identified variables and information collection was based on comprehensive literature review process. For example, previous studies employed literature review approach for suggesting new performance measures and metrics in supply chain management from the information integration perspective [49]. The research study followed the qualitative research methodology. The literature review consisted of different articles, case studies, books, live blogs, thesis, documents, and libraries stuffs. Around 50 articles have been reviewed to signify the importance of Critical Success Factors and its benefits to the organizations. Although ERP systems are complex in nature during implementation and there is no hard and fast rules to measure the success of the project statistically or mathematically but the convenient way of measurement is the Critical Success Factors. It is evident from the literature that some factors must be considered seriously during ERP system implementation for the organization success. Therefore, the paper focused to discuss and explore the Critical Success Factors to measure the success of ERP system implementation for competitive organizations. All the identified factors are represented in Fig 1 , and Table 2 discussed in this paper.

\subsection{Data Collection}

The process of data collection in this paper has been started with comprehensive literature review. The data collection sources are from different standard databases such as Science Direct, IEEE, Emerald Publishing Group, Open Access Journals, Proceedings, Google, and Google Scholars. As discussed in Section 2, the paper is based on literature and the data collected from articles, case studies, books, thesis, and libraries. The articles studied were both the proceedings and journals published by the standard databases. The proceedings papers were mostly downloaded from IEEE explorer, Google, and Google scholars. The main focus of this paper was on the ISI indexed journal latest publications that have updated data and clear problem statement in the recent advancement of ERP research. The case studies review process made clear the vision of this paper with the latest trend in research regarding ERP implementation with different cases and scenarios, the authors analyzed in their works. The role of online portals and blogs supplement the title o this paper with momentous materials. Another kind of contribution to this paper was the reviewing of books and student online thesis. The books contribution is not dominant but helped this work with the ideas of exploration of Critical Success Factors.

\section{CRITICAL SUCCESS FACTORS}

Critical success factors of ERP system implementation are the factors, where the ERP system implementation can be measured to its success [9]. Measurement of ERP implementation in figures or statistically is difficult task but it should be measure with these factors that how much it is working and how these factors are implemented successfully. Although ERP systems are integrated and consistent but on the other hand it is risky and complicated with software and resources. Return on investment of ERP project can be measure with the success factors which are common in each project during implementation. This paper will discuss some important critical success factors in the literature in brief way to identify that how the ERP project will go live with success and why it is fail for some reasons. The identified critical success factors are: Top Management, Change Management, Project Management, Business process Re-Engineering, IT Infrastructure, Communication, and User training. The mentioned factors are shown in figure 1 . Table 2 will discuss the common concepts of the researcher within the scope of the title of this paper.

\subsection{Top Management}

The role in ERP system implementation projects of Top Management is the most critical success factor and identified as consistently very decisive throughout the project implementation process $[1,6,18]$. Therefore top management is needed throughout the project to unequivocally identify the project as top priority [3]. Due to the complex nature and high budget projects of typical ERP implementation the scope of top management is the most important factor to support the project [4]. It is urged that top management must be having a clear vision planned project management, business processes re-engineering, user training, and effective communication that organizations get full benefits of the ERP complex system otherwise the risk of failure will be on the high level [5].For that reason Bhatti [1] has mentioned two aspects of top management that is leadership and the providing of necessary resources [1]. Moreover, top management is not only limited to initiation and facilitation but will must be extended to the full implementation of ERP system by directing the implementation team to monitor the progress throughout the project [5, 6]. According to Jarar et-al [6], HP noted that ERP implementation is about people not processes or technology [6]. The success of ERP implementation project is totally in the hand of leadership of the high level top management, which is very important to monitor the team [8]. Furthermore, Top management is the project champion from the middle management but it is now unclear how this person is effectively contributed to the success of ERP implementation [9].Therefore, the leadership have dominant influence to guide and coordinate the project team towards the goal accomplishment of the project [10] and author have classified the leadership in two categories that are: transformational leadership, that the relationship between the leader and the team as a form of transactions while the transactional 
leadership is the individual who follow the team in return for satisfaction and on the task throughout the project [10].

\subsection{Change Management}

Change management is another crucial and important critical success factors of ERP project implementation. To introduce ERP project in a company, change management is an important factor for successful implementation to structure the change management strategies and business process methodology to accomplish its goal [6]. As discussed in the literature that change management is a crucial factor of ERP implementation therefore it is essential to start it at the initial step and continue throughout the project for successful implementation [1]. The key task of ERP implementation team in change management strategies to build user acceptance and employees attitude towards the new system [8]. Change management system believes on changing the business process for an organization, so careful attention must be given to change management system $[1,2,7]$. "Organizational change refers to the body of knowledge that is used to ensure that a complex change, like that associated with a new big information system, gets the right results, in the right timeframe, at the right costs. The change management approach will try to ensure the acceptance and readiness of the new system, allowing the organization to get the benefits of its use. A successful organizational change approach relies in a proper integration of people, process and technology" [4]. The most common failure factor is the readiness of change as described by [3] based on [19] because ERP system completely changes the culture of organizations where many companies found hard to achieve this successfully $[3,19]$. Furthermore, many companies identified that ERP implementation fail to accomplish the desired benefits because they underestimate the efforts involved in change management [1].

\subsection{Project Management}

ERP system is actually a project management approach for organizations to have its integrated system and well defined business processes. Therefore, ERP projects like other projects need management in: business planning, human resources, time and cost. Moreover, Project management is the management of implementation planning, therefore it involves not only the planning stages but also the apportion of responsibilities to various players, the definition of milestones and critical paths, training and human resource planning, and finally the determination of measures of success [8, 20].According to Bhatti [1] that, "Project Management involves the use of skills and knowledge in coordinating the scheduling and monitoring of defined activities to ensure that the stated objectives of implementation projects are achieved. The formal project implementation plan defines project activities, commits personnel to those activities, and promotes organizational support by organizing the implementation process" [1]. "Finney and Corbett [8] based on [18, 21], advocated that the need to built a steering committee composed of senior management from corporate functions, senior management reps, and ERP end users. These responsibilities of the committee members involve ERP selection, implementation monitoring, and consultant management" [8].

\subsection{Business Process Re-Engineering}

Business process re-engineering is one of the important step in ERP implementation. Software selection and customization according to the organization requirements to best fit in it is another issue in this step. Therefore business process reengineering is critical success factor of ERP Implementation because of the complex nature of software selection and customizations.

"Business process re-engineering is taking place in two ways, either to change the business processes to accommodate the software for long established way of doing business and shakeup the important people's role and responsibilities or to modify the software to fit business processes. The first way the author mentioned with competitive advantages while the later one will slow down the project and is risky to introduce the dangerous bugs into the system and the upgrading of the software to ERP will be difficult" [6]. Re-engineering is a continuous process with new ideas to be added to have full benefits of ERP system in the running system of organizations $[23,5]$. To reduce the degree of customization organizations must be agree to change their processes in order to fit the software $[24,5]$. The final decision will be from the manager to either re-engineer the business process during, after or before the ERP implementation [4]. To do changes to software or customization to ERP software it should be according to the organization requirements and no additional complex changes should be made to ease the process of implementation [23]. " Al-Fawaz et-al [5] based on [21, 22], described that the new business model and reengineering that drives technology choice is an enabling factor that can give to ERP success".

\subsection{IT Infrastructure}

IT infrastructure is another critical success factor of ERP system implementation. It is critical to evaluate the IT infrastructure and skills of an organization but if necessary the infrastructure should be upgraded or restored $[8,18,21]$. On the other hand Jarrar et-al [6] pointed that sufficient hardware and networking infrastructure is essential before going to ERP implementation because a strong IT infrastructure is required for ERP applications [6]. Because IT infrastructure contains building business processes, IT cost reduction and IT infrastructure [15]. Hardware selection is the company choice but usually the ERP software vendors select the appropriate hardware that which hardware is more accurate to run the ERP applications [1]. Moreover, the crucial impact on ERP implementation is the configuration of software and can affect the outcome of the implementation process [2,6]. Object oriented technology has a massive role in IT infrastructure and business information system to overcome the software crises. Through object oriented modeling many small and medium size organizations has proven an excellent techniques for modeling business processes in companies [10].On technical perspective a strong IT infrastructure support the business vision, while the decentralized and legacy infrastructure can rupture a company [2]. It is evident that ERP system implementation integrate the information system, business process and IT infrastructure in organizations [1].Moreover, companies are turning towards ERP solutions for information technology planning and legacy systems management [2].

\subsection{Communication}

For successful ERP system implementation it is necessary to have an effective communication between the individual employees and the project team of an organization. Many researchers and author pointed out that communication is the challenging task in ERP system implementation [5, 15]. [4] 
described two types of communication: inward communication mean the project team and outward communication between the whole organization. So it is clear that communication is not only limited to the project team but the information sharing must be done throughout the organization [4]. Therefore, it is a critical successes factor to communicate between business and IT personnel [8]. Effective communication in the project facilitates troubleshooting although it might be difficult with some problems such as local business process [2]. But the communication efforts must be done during implementation phases [4]. Communication should be started at the initial stages of the project which is included the overview of the system and will lead to be consistent and continue throughout the project [1]. For effective communication, a communication plan is imperative factor to ensure that effective communication take place in the entire organization, including employees as well as customers and suppliers [8, 26]. Communication plan have detail of: justification of ERP implementation, business process management change, manifestation of appropriate software modules, consultation of change management strategies, and tactics and establishment of contact points [15, 27]. Moreover, Communication has to wrap the scope, purpose, and tasks of an ERP implementation project $[15,26]$.

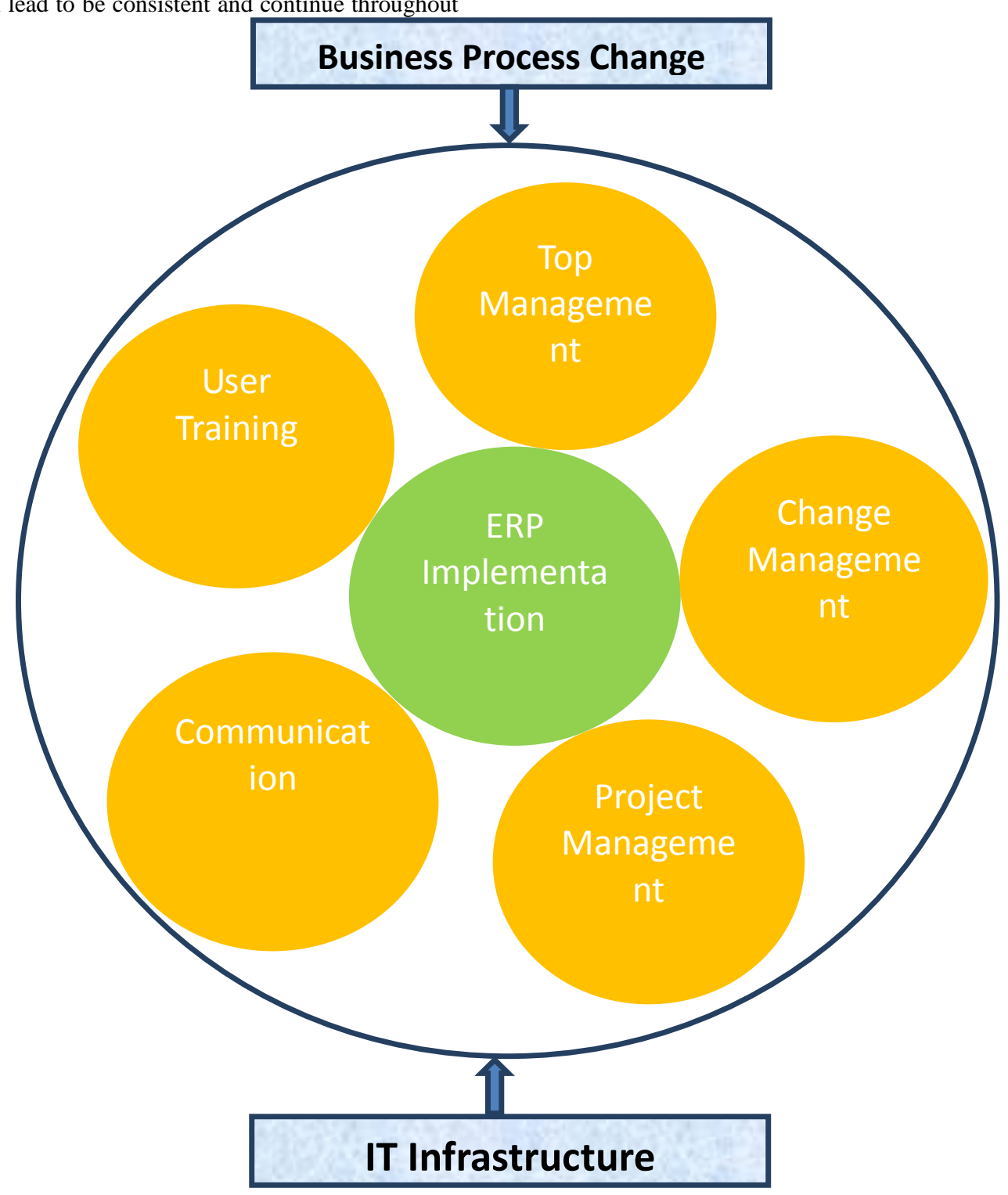

Figure 1: Critical Success Factors of ERP System Implementation 


\subsection{User Training}

The last stage in ERP system implementation is user/employees training. A company will never get benefits from the ERP system until the employees have no knowledge that how to operate the new system [6]. The main reason of user training and education program to ensure that employees are comfortable with the ERP system and to increase the expertise and knowledge of users [2].ERP system installation without appropriate training can lead the system to failure [6]. Therefore training doesn't mean only to operate the new system but also to understand the new processes and the integration within the system that how the work of one user manipulates the work of other user [2]. Some authors in the literature has described that user training is not only limited to the users but also needed for the project team, but all others agreed specifically on the user training [8]. ERP is a complex system and without appropriate training it is intricate to use the system even the user have strong IT skills [5, 27]. It is important for both end users and technical staff to focus on training because training help the ERP project to increase success of ERP systems implementation $[3,4,5]$. The main objective of this step in ERP implementation is to introduce the expertise and knowledge to the users in a company $[5,28]$.

Training and education in both senses are necessary to have hand-on expertise in knowledge about the ERP system and its operation and IT skills that are used for IT and business people [7]. Hand-on expertise in the ERP system and well trained people assist the project to increase the chances of success of the project, while lack of knowledge and training can lead the project to failure $[5,22]$. Some organizations have adopted to use in-house training approach while other organizations use the consultants training approach [4]. ERP related concepts, scopes and training expertise are all the magnitudes of ERP training program for ERP system implementation [2].

Table 2: Critical Success Factors of ERP System Implementation in the literature

\begin{tabular}{|c|c|c|}
\hline S. No. & Critical Success Factors & References / Related Work \\
\hline 1. & Top Management & $\begin{array}{l}\text { Bhatti. T. R., (2005); Kalbasi. H., (2007); Esteves-Sousa. J.,\& Pastor-Collado. J., } \\
\text { (2000); Al-Fawaz. K et al (2008); Jarrar. Y. F., et al (2000); Finney. S., \& Corbett. } \\
\text { M., (2007); Shanks. G., et al (2000); Doom. C. \& Milis. K. (2008); Basu. R. } \\
\text { \&Adhikary. R.; Somers. T. M. \& Nelson. K. G, (2004); Doom et al. (2010) }\end{array}$ \\
\hline 2. & Change Management & $\begin{array}{l}\text { Bhatti. T. R., (2005); Kalbasi. H., (2007); Esteves-Sousa. J.,\& Pastor-Collado. J., } \\
\text { (2000); Jarrar. Y. F., et al (2000); Finney. S., \& Corbett. M., (2007); Shanks. G., et } \\
\text { al (2000);Gargeya. V. B. \& Brady. C, (2005); Doom et al. (2010) }\end{array}$ \\
\hline 3. & Project Management & $\begin{array}{l}\text { Bhatti. T. R., (2005); Al-Fawaz. K et al (2008); Finney. S., \& Corbett. M., (2007); } \\
\text { Nah. F. F-H. et al (2001); Somers, T.M. \& Nelson, K. G., (2001); Somers, T.M. \& } \\
\text { Nelson, K. G., (2004), Doom et al. (2010). }\end{array}$ \\
\hline 4. & $\begin{array}{l}\text { Business Process } \\
\text { Re-Engineering }\end{array}$ & $\begin{array}{l}\text { Bhatti. T. R., (2005); Esteves-Sousa. J.,\& Pastor-Collado. J., (2000); Al-Fawaz. K } \\
\text { et al (2008); Jarrar. Y. F., et al (2000); Somers, T.M. \& Nelson, K. G., (2001); } \\
\text { Somers, T.M. \& Nelson, K. G., (2004); Nah, F.F-H., et al (2003); Murray, M., \& } \\
\text { Coffin, G. (2001). }\end{array}$ \\
\hline 5. & IT Infrastructure & $\begin{array}{l}\text { Bhatti. T. R., (2005); Holland. C. P. \& Light. B., (1999); Jarrar. Y. F., et al (2000); } \\
\text { Finney. S., \& Corbett. M., (2007); Basu. R. \&Adhikary. R.;Somers, T.M. \& } \\
\text { Nelson, K. G., (2001); Somers, T.M. \& Nelson, K. G., (2004); Holland. C.\& } \\
\text { Light. B., (1999), Doom et al. (2010). }\end{array}$ \\
\hline 6. & Communication & $\begin{array}{l}\text { Bhatti. T. R., (2005); Holland. C. P. \& Light. B., (1999); Kalbasi. H., (2007); } \\
\text { Esteves-Sousa. J.,\& Pastor-Collado. J., (2000); Finney. S., \& Corbett. M., (2007); } \\
\text { Kumar. V., (2002); Bancroft. N., (1998); Sumner. M., (1999). }\end{array}$ \\
\hline 7. & User Training & $\begin{array}{l}\text { Holland. C. P. \& Light. B., (1999); Kalbasi. H., (2007); Esteves-Sousa. J.,\& } \\
\text { Pastor-Collado. J., (2000); Finney. S., \& Corbett. M., (2007); Al-Fawaz. K et al } \\
\text { (2008); Jarrar. Y. F., et al (2000); Shanks. G., et al (2000); Doom. C. \&Milis. K.; } \\
\text { Woo. H., (2007); Zhang. L., (2003); Nah, F.F-H., et al. (2003), Doom et al. } \\
\text { (2010). }\end{array}$ \\
\hline
\end{tabular}

\section{DISCUSSION AND CONCLUSION}

This paper presents the inclusive anthology of the Critical Success Factors identified in the literature with a clear and structured methodology approach [8]. The exploration and identification of the critical success factors are based on thorough study of the literature review. The identified critical success factors are: Top management, Change management, Project Management, Business process Re-engineering, IT Infrastructure, Communication, and User Training as shown in Fig 1. All the mentioned literature in this paper agreed on the same factors which are critical for the successful ERP implementation as shown in Table 2. It is evident from the previous work of the researcher in the same field that ERP system implementation is a challenging task and lead to be risky if not considered carefully. For this reason the top management of any ERP system implementation project is responsible to manage it carefully by providing all the resources and leadership to its success. Business plan, project vision and management, business processes re-engineering, hiring of high profiled consultants all are included in the responsibilities of top management. Without Top management support in these responsibilities no organization can embrace the full benefits of ERP system and the risk should be in high level. Change management is considered to be the most crucial success factor of ERP System implementation. Change management believes on changing the internal system 
completely or partially with new sophisticated technologies. Changing in the system with new technology, the end user reaction against the new system cannot be ignored to discuss in the change management strategies. It is evident from the previous work that most of the ERP system implementation failed due to end users reaction against the new and the complex technology of ERP system [9]. The end user reactions against the new system is due to many reasons such as: political issues, old style people, low education employees, and technology enemy people [14]. To implement the system successfully Top Management should care about all these issues including the end users reaction. The end user reaction can be handled with effective training for the new system to introduce the technology and provide them with some motivating incentives that employees may take interest to operate the system effectively.

Project management is another issue in ERP system implementation. The project manager should take care of the project budget, time and scope. In the literature, It is discussed that many projects failed due to time restrictions and were not completed within the time they fix for it. So time within budget is the top priority of every project manager in ERP implementation. Project management is not only limited to the planning phases but they should be focus on human resources and outcome of the project. The outcome of the project should be measure with return on investment (ROI). The IT infrastructure must be defined before the project implementation. Sufficient hardware and network resources must be defined for ERP application before the installation of new system. Sophisticated IT infrastructure relies on the operation of ERP system with software configuration for successful implementation [6]. As discussed in the literature that, to overcome the software crises, object oriented technology is an excellent option to be used to develop business information system for organizations.

Before going to any ERP system to select for implementation with customization techniques it is needed to analyze the organization requirement. Customization of software system according to the requirements of organization is very critical and should be defined in advance. The organization culture should be collaborative with effective communication between the departments of the entire organization. The information flow and sharing of knowledge between IT personals and business people must be fluent and on regular bases to get all the benefits of individual's knowledge.

User training is the most crucial and important step in the ERP system implementation. As discussed above that almost the ERP system projects failed due to users reaction against the new system due to many reason discussed above. To recover this problem, it is the responsibility of the top management to arrange user training for the new and complex ERP system technologies. Different consultant should be hire to train the user in very polite way. The company cannot get all the benefits if the users unable to operate the system effectively. The main purpose of training to the users to ensure them they are comfortable with the new system in operating and understanding.

\section{ACKNOWLEDGMENTS}

Author extends their appreciations to the Deanship of Scientific Research at King Saud University, Riyadh for funding the work through the research group project No. RGP-VPP-208.

\section{REFERENCES}

[1]. Bhatti. T. R., (2005), Critical Success Factors For The Implementation Of Enterprise Resource Planning (ERP): Empirical Validation, The Second International Conference on Innovation in Information Technology (IIT'05)

[2]. Holland. C. P., Light. B., (1999), A Critical Success Factors Model For ERP Implementation, Software IEEE, Journal and magazines, volume 16 Issue 3, pp 30-36.

[3]. Kalbasi. H., (2007), Assessing ERP Implementation Critical Success factors, Master Thesis continuation courses marketing and E-Commerce,Pages 78,http://epubl.ltu.se/1653-0187/2007/041/LTU-PB-EX07041-SE.pdf,Accessed Date: April 9, 2012.

[4]. Esteves-Sousa. J., Pastor-Collado. J., (2000), TOWARDS THE UNIFICATION OF CRITICAL SUCCESS FACTORS FOR ERP IMPLEMENTATIONS, Published in 10th Annual Business Information Technology (BIT) Conference, Manchester

[5]. Al-Fawaz. K., Al-Salti. Z., Eldabi. T., (2008), Critical Success Factors In Erp Implementation: A Review, European and Mediterranean Conference on Information Systems 2008 (EMCIS2008) May 25-26 200, Al BustanRotana Hotel, Dubai

[6]. Jarrar. Y. F.,Al-Mudimigh. A.,Zairi. M., (2000), ERP Implementation Critical Success Factors -The Role And Impact Of Business Process Management, Proceedings of the 2000 IEEE International Conference on Management of Innovation and Technology, pp122-127.

[7]. Shanks. G., Parr. A., Hu. B., Corbitt. B., Thanasankit. T., Seddon. P., (2000), Differences in Critical Success Factors in ERP Systems Implementation in Australia and China: A Cultural Analysis, In proceedings of the 8th European Conference on Information Systems, pages 8.

[8]. Finney. S., Corbett. M., (2007), ERP implementation: a compilation and analysis of critical success factors, Business Process Management Journal Vol. 13 No. 3, pp. 329-347.

[9]. Doom, C., Mills, K., Poelmans, S. and Bloemen, E. (2010), Critical success factors for ERP implementation in Belgian SMEs, Journal of Enterprise Information Management, vol. 23 Iss. 3, pp. $378-406$

[10].Basu. R., Adhikary. R., Critical Success Factors of ERP Implementation for Small and Medium-Size Companies,Human Resources Outsourcing Information, http://www.articlesbase.com/electronics-articles/criticalsuccess-factors-of-erp-implementation-for-small-andmediumsize-companies-2130772.html, Accessed Date: April 04, 2012.

[11].ALdayel. A. I., Aldayel. M .S., Al-Mudimigh. A .S., (2011), The Critical Success Factors of ERP implementation in Higher Education in Saudi Arabia: A Case Study, Journal of Information Technology and Economic Development 2(2), 1-16.

[12].Dezdar. S., Sulaiman. A., (2009), Successful enterprise resource planning implementation: taxonomy of critical 
factors, Industrial Management \& Data Systems Vol. 109 No. 8, pp. 1037-1052.

[13].Skok. W., Legge. M., (2002), Evaluating Enterprise Resource Planning (ERP) Systems using an Interpretive Approach, Knowledge and Process Management Volume 9 Number 2 pp 72-82.

[14].Al-Shamlan H. M., Al-Mudimigh. A. S., (2011), The Chang Management Strategies and Processes for Successful ERP Implementation: A Case Study of MADAR, IJCSI International Journal of Computer Science Issues, Vol. 8, Issue 2, pp 399-407.

[15].Al-Mashari.M., Al-Mudimigh. A., Zairi. M., (2003), Enterprise resource planning: A taxonomy of critical factors, European Journal of Operational Research, Vol. 146, pp 352-364.

[16].Dezdar. S., Sulaiman. A., (2009), Successful enterprise resource planning implementation: taxonomy of critical factors, Industrial Management \& Data Systems, Vol. 109 No. 8, pp. 1037-1052.

[17].Brown. D. H., He. S., (2007), "Patterns of ERP adoption and implementation in China and some implications", Electronic Markets, Vol. 17 No. 2, pp. 132-41.

[18].Somers. T. M., Nelson. K. G, (2004) "A taxonomy of players and activities across the ERP project life cycle", Information \& Management, vol. 41, pp 257-278.

[19].Gargeya. V. B., Brady. C, (2005), Success and failure factors of adopting SAP in ERP system implementation, Business Process Management Journal, Vol. 11 Iss: 5, pp. $501-516$.

[20].Nah. F. F-H., Lau. J. L-S., Kuang, J. (2001), “Critical factors for successful implementation of enterprise systems", Business Process Management Journal, Vol. 7, p. 285-296.

[21].Somers, T.M., Nelson, K. G., (2001), The impact of critical success factors across the stages of enterprise resource planning implementations, Proceeding of the 34th Hawaii International Conference on System Sciences.

[22].Nah, F.F-H., Zuckweiler, K.M., et al. (2003), ERP implementation: chief information officers' perceptions of critical success factors', International Journal of Human-Computer Interaction, vol. 16(1), pp 5-22.

[23].Murray, M., Coffin, G. (2001), A case study analysis of factors for success in ERP system implementations'. Proceedings of the Seventh Americas Conference on Information Systems, Boston, 1012-1018.

[24].Kumar. V., Maheshwari. B., Kumar. U., (2002), ERP systems implementation: best practicesin Canadian government organizations, Government Information Quarterly, Vol. 19, pp. 147-72.

[25].Bancroft. N., Seip. H., Sprengel. A., (1998), Implementing SAP R/3: How to Introduce a Large System into a Large Organization, Manning Publication Co., Greenwich, CT.

[26].Sumner. M., (1999), Critical success factors in enterprise wide information management systems projects, In Proceeding of the SIGCPR_99, New Orleans, LA.
[27].Woo. H., ( 2007), 'Critical success factors for implementing ERP: the case of a Chinese electronics' manufacturer Journal of Manufacturing Technology Management 18 (4), pp 431-442.

[28].Zhang. L., Lee. M. K. O., Zhang. Z., Banerjee. P., (2003), Critical Success Factors of Enterprise Resource Planning Systems Implementation Success in China, Proceedings of the 36th Hawaii International Conference on System Sciences.

[29].Inkpen, A. and Ramaswamy, K. (2007), End of the multinational: emerging markets redraw the picture, Journal of Business Strategy, Vol. 28 Iss: 5, pp.4 - 12

[30].Avegerou (2001) The significance of context in information systems and organisational change, Information Systems Journal, 11, pp. 43-63.

[31].Vignali, C. (2001) McDonald's: "think global, act local the marketing mix, Emerald 103, doi $10.1108 / 00070700110383154$

[32].Parker, B. (2005), Introduction to Globalisation and Business: Relationships and Responsibilities, Sage Publication, ps. 536

[33].Rashid, M. Z. A, Sambasivan, M. and Rahman, A. A. (2004) The influence of organizational culture on attitudes toward organizational change, Leadership \& Organization Development Journal, Vol. 25 Iss: 2, pp.161 - 179

[34].Grewal and Tansuhaj (2001) Building organisational capabilities for managing economic crisis: The role of market orientation and strategic flexibility, Journal of Marketing, Vol. 64 (April issue), p. 67-80.

[35].Lan, Y. and Unhelkar, B. (2006), Global Integrated Supply Chain Systems, Idea Group Publishing.

[36].Matthyssens, P, Kirca, A. H., Pace, S. (2008) Businessto-business marketing and globalization: two of a kind, International Marketing Review, Vol. 25 Iss: 5, pp.481 486

[37].Lemoine, W and Dagnæs, L. (2003) Globalisation strategies and business organisation of a network of logistics service providers, International Journal of Physical Distribution \& Logistics Management, Vol. 33 Iss: 3, pp. $209-228$

[38].By, R. T. (2005) Organisational change management: A Critical Review, Journal of Change Management, vol. 5, No. 4, pp. 369-380.

[39].Magutu, P. O., Nyamwange, S. O. and Kaptoge, G. K. (2010) Business ProcessReengineering ForCompetitive Advantage: Key Factors That May Lead To The Success Or Failure Of TheBPR Implementation (The Wrigley Company), African Journal of Business \& Management (AJBUMA), Vol. 1, 16 pages.

[40].McNulty, T. and Ferile E. (2004), Process Transformation: Limitations to Radical Organisational change within Public Service Organisations, Studies, Vol. 25, Iss. 8, pp.1389-1412, Sage Publications

[41].Holland, C. P. and Light, B. (1999) Global Enterprise Resource Planning Implementation, Proceedings of the 32nd Hawaii International Conference on System Sciences, Jan 5-8, Island of Maui, Hawaii 
[42]. Grover, V. (1999), From Business Reengineering to Business Process Change Management: A Longitudinal Study of Trends and Practices, IEEE Transactions On Engineering Management, Vol. 46, No. 1, pp. 36-46

[43].Anonymous (undated), Chapter 3: Strategic decision Making available at: http://highered.mcgrawhill.com/sites/d1/free/007078051x/576222/baL8051x_ch0 3.pdf (accessed on October 1, 2012), McGraw Hill Publications

[44].Voordijk, H., Leuven, A.V. and Laan, A. (2003), Enterprise resource planning in a largeconstruction firm: implementation analysis, Construction Management and Economics, Vol. 21, p. 511.

[45].Davenport, T. H. (1998), Putting the enterprise into the enterprise system. Harvard Business Review, (JulyAugust), pp. 121-131.

[46].Kumar. V., Maheshwari. B., Kumar. U., (2003), An investigation of critical management issues in ERP implementation: empirical evidence from Canadian organistions, Technovation 23, 793-807.

[47].Sari, N. A. Hidayanto, A. N. and Handyani, P. W. (2012), Toward catalog of Enterprise Resource Planning (ERP) Implementation Benecits: An Empirical Analysis of an Indonasian Agriculture Company, 19th IBIMA Conference, 12-13 November, Barcelona, Spain.
[48].Shang, S. and Seddon, P. B. (2002), Assessing and measuring the business benefits of enterprise systems: The business manager's perspective, Information Systems Journal (12:4), pp. 271-299.

[49].AlSudairi, M. and Dwivedi, Y. K. (2010), A multidisciplinary profile of IS/IT outsourcing research, Journal of Enterprise Information Management Vol. 23 No. 2, pp. 215-258.

[50].AlSudairi, M. A. T and Vasista, T. G. K. (2012), Design of Strategic Business Model for Electronic Enterprise in Digital Society, International Journal of Digital Society (IJDS), Volume 3, Issues 3 and 4, (September/December), pp. 690-697.

[51].Porter, M. (1985), Competitive Advantage: Creating and sustaining superior Performance, New York: Free Press.

[52].Henderson, J.C. and Venkatraman, N. (1992). Strategic Alignment: A model for organizational transformation through information technology, in T.A. Kocham and M. Useem (eds.) Transforming organizations, first edition, New York: Oxford University Press, pp. 97-117.

[53].Spathis, C., and Constantinides, S. (2003) The usefulness of ERP systems for effective management, Industrial Management \& Data Systems, Vol. 103 Iss: 9, pp.677 685 . 